\title{
Investment development path: the applicability of measurement criteria and further development
}

Ke Dai ${ }^{1, *}$

${ }^{1}$ Business School, Hohai University, Nanjing City, Jiangsu Province, 2111100, China

\begin{abstract}
With China's reform and opening up, the relationship between foreign direct investment and economic development gradually attracts attention. Professor Dunning first developed this theory, which describes the division of net outward direct investment into four distinct stages of a country's economic development, and later increased it to five. The theory has been developed for 40 years, and whether it can survive and still play a guiding role in national development is the focus of people's concern. Based on the previous studies of scholars, this paper conducts an empirical study on "individual" countries. Thus it is concluded that the theory in its net foreign direct investment and economic development of the important relationship of the original is still valid, but from the cross section, the measures to be improved, and the theory of the fifth stage of the development of a new understanding
\end{abstract}

\section{Introduction}

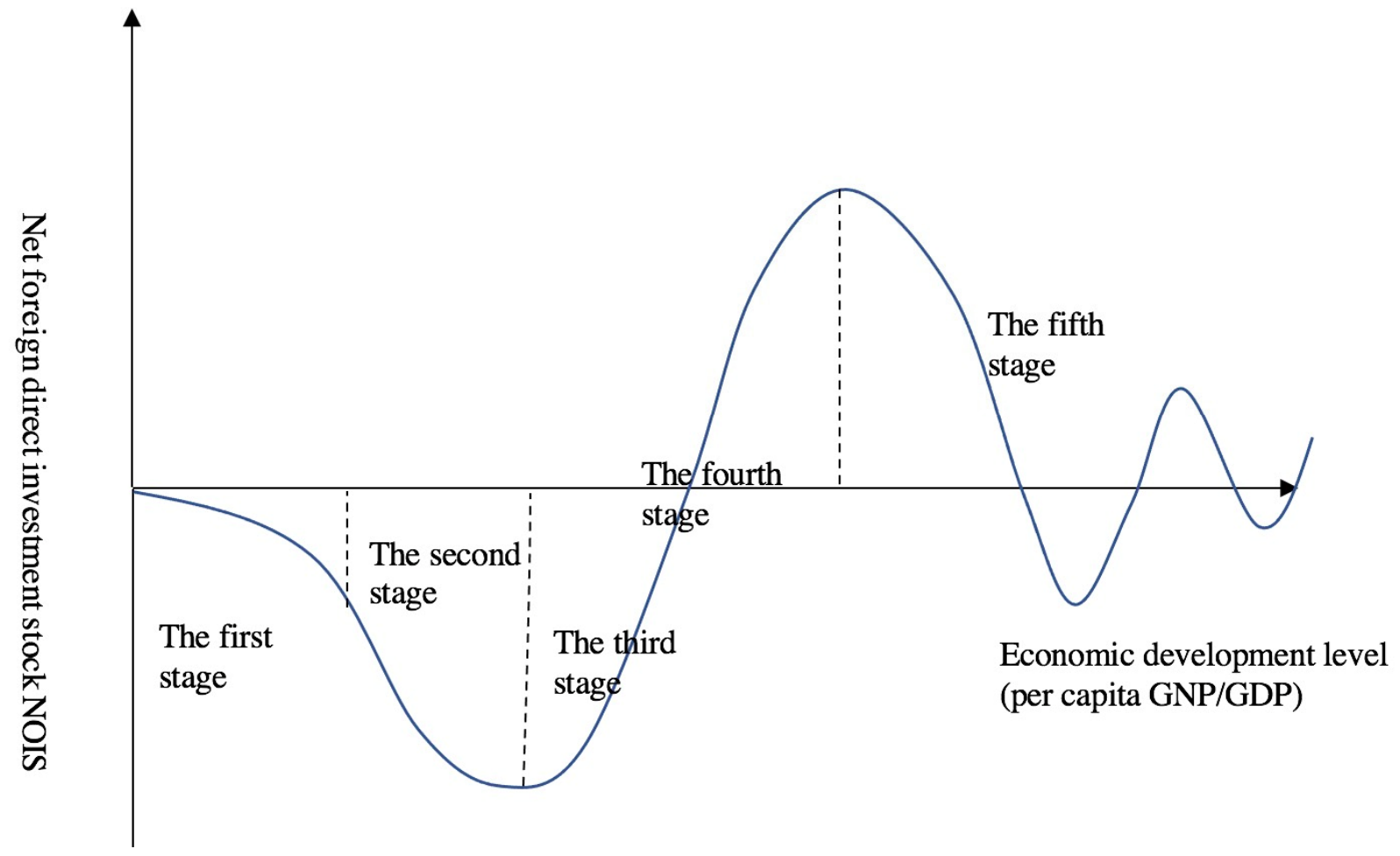

Figure 1.IDP theory qualitative drawing.

*Ke Dai: dk15850671196@163.com 
According to IDP theory (Theory of Investment Development Path), the per capita GNP standards of each stage were reclassified and summarized in the above figure 1 with Dunning's theory. ${ }^{[i]}$

As can be seen from Figure 1, according to the qualitative analysis, the net foreign direct investment of a country with the change of GNP per capita in the second and third stages can present a "U-shaped", and the second and third stages are divided by inflection point. After the intersection with the $\mathrm{X}$ axis, it becomes the mark of the third and fourth stages. The fourth and fifth stages present an "inverted U shape". Among them, "(inverted) U-shape" can be fitted by quadratic function, but it is difficult to carry out empirical study in the first and fifth stages. It is found that previous scholars Buckle and Castro (1998) proposed the penttic model. ${ }^{[i]}$

\section{Empirical analysis: the investment development path of each country respectively test and stage division}

The empirical methods used below mainly include the quadratic model and the quintic model to fit the net foreign direct investment (NOIS) and per capita GNP (GNPPC). I selected the best fitting model for each country as the model of that country. According to the fitting objects, the empirical analysis is divided into three parts: major developing countries, major developed countries.

$$
\begin{aligned}
& \text { Secondary model: } N O I S=A+B_{1} G N P P C+B_{2} G N P P C^{2}+U \\
& \text { The quintic model: } N O I S=A+B_{1} G N P P C^{3}+B_{2} G N P P C^{5}+U
\end{aligned}
$$

\subsection{Developing countries}

Emerging markets are markets with gradually improved market economic systems. Its main features are low labor costs and abundant natural resources. Emerging markets are the major recipients of global capital inflows. Unlike in the $1990 \mathrm{~s}$, this time it was not speculation in stocks and bonds, but foreign direct investment. According to the IMF, net foreign investment in these countries increased by $92 \%$, while net investment in stocks and bonds fell slightly. Large multinational companies represented by the world's top 500 plan to increase their direct investment in emerging countries such as China, India, Brazil and Russia in the future. It has become routine for big Western companies to outsource to emerging countries.

The research on the development path of investment in developing countries will also help us to understand China's future direction and provide a basis for policies. The following is the process of empirical test on the selected major developing countries of "BRIC" China, Brazil, Russia and India:

\begin{tabular}{|c|c|c|c|c|}
\hline & $\begin{array}{l}\text { China (Secondary } \\
\text { Model) }\end{array}$ & $\begin{array}{l}\text { Brazil (Secondary } \\
\text { Model) }\end{array}$ & Russia & India (secondary model) \\
\hline GNPpc coefficient & 171.218 & 29.07164 & & 34.11573 \\
\hline $\begin{array}{l}\mathrm{GNPpc}^{\wedge} 2 \\
\text { coefficient }\end{array}$ & 0209678. & 0002149. & & -040831 \\
\hline T test (coefficient) & significant & significant & & significant \\
\hline $\mathrm{F}$ & Prob $>F=0.0000$ & Prob $>F=0.0000$ & Prob $>F=0.0041$ & Prob $>F=0.0000$ \\
\hline $\mathrm{R}^{\wedge} 2$ & 0.8091 & 0.52580 .0000 & 0.3801 & 0.9723 \\
\hline $\begin{array}{l}\text { Whether it is } \\
\text { significant } \\
\text { (consistent) }\end{array}$ & Significant in & Significant in & $\begin{array}{l}\text { Do not conform to } \\
\text { the }\end{array}$ & Significant in \\
\hline $\begin{array}{l}\text { Investment position } \\
\text { stage }\end{array}$ & $\begin{array}{l}\text { 1, since the quadratic } \\
\text { function inflection point } \\
\text { - } \mathrm{B} / 2 \mathrm{a}=4082.889(2009- \\
2010) \text { to enter the third } \\
\text { stage } \\
\text { 2. Enter the fourth stage } \\
\text { from the point of } \\
\text { intersection with X-axis } \\
(2015-2016)\end{array}$ & $\begin{array}{l}\text { The image produces a } \\
\text { fault, unable to find the } \\
\text { inflection point, most of } \\
\text { the net outward } \\
\text { investment is below the } \\
\text { X-axis, judged in the } \\
\text { second or third stage }\end{array}$ & & $\begin{array}{l}\text { There is no inflection } \\
\text { point } \\
\text { It's always negative, and } \\
\text { the absolute value is } \\
\text { increasing, so it's in the } \\
\text { second stage }\end{array}$ \\
\hline GNPpc phase & $\begin{array}{l}\text { According to Dunning } \\
\text { (1981) : } \\
\text { 1. The inflection point is } \\
\text { divided into the fourth } \\
\text { stage according to } \\
\text { GNPPC } \\
\text { 2. GNP at the } \\
\text { intersection of X axis is }\end{array}$ & $\begin{array}{l}\text { According to Dunning } \\
\text { (1981): } \\
\text { Brazil is in the third and } \\
\text { fourth stages } \\
\text { World Investment } \\
\text { Development Report } \\
\text { (2006): mainly in the } \\
\text { second stage (there are }\end{array}$ & & $\begin{array}{l}\text { According to Dunning } \\
(1981) \text { : } \\
\text { India is in the second } \\
\text { phase } \\
\text { World Investment } \\
\text { Development Report } \\
(2006) \text { : }\end{array}$ \\
\hline
\end{tabular}

Table 1. Comparison of IDP optimal model test results of major developing countries "BRIC" 


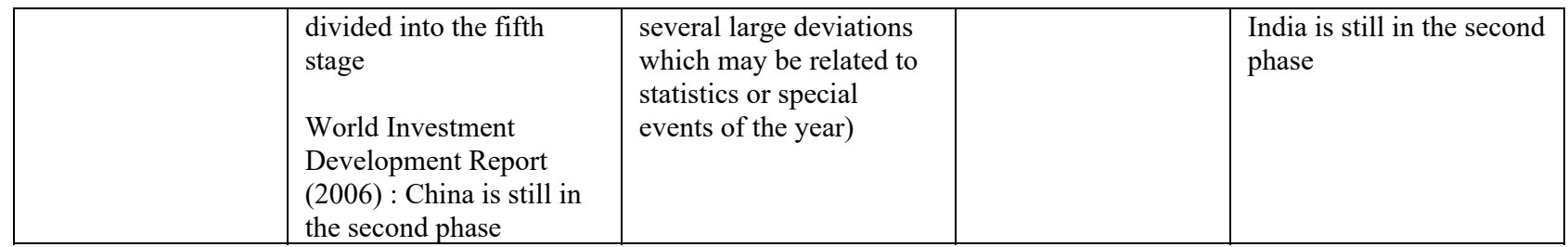

In developing countries, the quadratic model is mainly used to achieve good fitting effect. Therefore, from the perspective of the relationship between a country's investment status and economic development, IDP theory well puts forward such an idea. However, according to the Dunning (1981) criterion, investment lags behind economic development to a large extent. According to the World Investment Development Report (2006), economic growth lags behind investment (the second phase ranges from $\$ 2,500$ to $\$ 10,000)$. [iii]Therefore, from the perspective of measurement standard, both of them have certain problems, and it is necessary to study the measurement standard again.

Different countries do have heterogeneity, and even some countries' investment development paths do not conform to the situation described by this theory, which may be closely related to the reasons (such as political policies) behind the ownership power, location advantage and market internalization advantage in OLI theory (The Eclectic Theory of International Production) of different countries. ${ }^{[\mathrm{iv}]}$
Among several countries, China is the country that most conforms to the description of this theory, and my empirical results (1980-2018) are consistent with the previous research results of scholars. The latest research of previous scholars up to 2007 showed that China was still in the second and third stage at that time. After more than a decade of development, China has gradually entered the fourth stage in terms of investment status.

\subsection{Developed countries}

It refers to those countries with high level of economic and social development and people's living standards, also known as high economic development countries (MEDC).The common characteristics of developed countries are high human development index, per capita gross national product, industrialization level and quality of life.

Table 2. Comparison of IDP optimal model test results in developed countries

\begin{tabular}{|c|c|c|c|c|c|c|c|}
\hline & $\begin{array}{c}\text { USA } \\
\text { (quinquennial } \\
\text { model) }\end{array}$ & $\begin{array}{c}\text { France } \\
\text { (quinquennial } \\
\text { model) }\end{array}$ & $\begin{array}{c}\text { Germany } \\
\text { (quinquennial } \\
\text { model) }\end{array}$ & $\begin{array}{c}\text { Japan } \\
\text { (Secondary } \\
\text { Model) }\end{array}$ & $\begin{array}{c}\text { Singapore } \\
\text { (Secondary } \\
\text { Model) }\end{array}$ & $\begin{array}{c}\text { Australia } \\
\text { (Secondary } \\
\text { Model) }\end{array}$ & $\begin{array}{c}\text { Canada } \\
\text { (quinquennial } \\
\text { model) }\end{array}$ \\
\hline $\begin{array}{c}\text { Coefficient of } \\
1\end{array}$ & $2.54 \mathrm{e}-08$ & $1.41 \mathrm{e}-08$ & $5.11 \mathrm{e}-09$ & 15.41429 & 5.056809 & 2.060261 & 4.99 e- 09 \\
\hline Factor of 2 & $6.87 \mathrm{e}-18$ & $3.65 \mathrm{e}-18$ & $3.85 \mathrm{e}-20$ & 0006497. & - 0001924. & $6.38 \mathrm{e}-06$ & -1.46 e-18 \\
\hline $\begin{array}{c}\mathrm{T} \text { test } \\
\text { (coefficient) }\end{array}$ & significant & significant & general & A significant & significant & A significant & significant \\
\hline $\mathrm{F}$ & $\begin{array}{c}\text { Prob }>F= \\
0.0000\end{array}$ & $\begin{array}{c}\text { Prob }>F= \\
0.0000\end{array}$ & $\begin{array}{c}\text { Prob }>F= \\
0.0000\end{array}$ & $\begin{array}{c}\text { Prob }>F= \\
0.0000\end{array}$ & $\begin{array}{c}\text { Prob }>F= \\
0.0000\end{array}$ & $\begin{array}{c}\text { Prob }>F= \\
0.0000\end{array}$ & $\begin{array}{c}\text { Prob }>F= \\
0.0006\end{array}$ \\
\hline $\mathrm{R}^{\wedge} 2$ & 0.5112 & 0.8819 & 0.8330 & 0.4495 & 0.9488 & 0.7463 & 0.3376 \\
\hline $\begin{array}{l}\text { Whether it is } \\
\text { significant } \\
\text { (consistent) }\end{array}$ & $\begin{array}{c}\text { More } \\
\text { significant } \\
\text { coincidence }\end{array}$ & Significant in & $\begin{array}{c}\text { More } \\
\text { significant less } \\
\text { consistent }\end{array}$ & $\begin{array}{c}\text { More } \\
\text { significant and } \\
\text { more } \\
\text { consistent }\end{array}$ & Significant in & $\begin{array}{c}\text { More } \\
\text { significant and } \\
\text { more consistent }\end{array}$ & $\begin{array}{l}\text { (only part of it } \\
\text { can be } \\
\text { explained by a } \\
\text { function) }\end{array}$ \\
\hline $\begin{array}{c}\text { Investment } \\
\text { position stage }\end{array}$ & $\begin{array}{l}\text { Stage } 4 \text { to } \\
\text { Stage } 5\end{array}$ & $\begin{array}{l}\text { The fourth to } \\
\text { the late fifth } \\
\text { stage of the } \\
\text { rally }\end{array}$ & $\begin{array}{l}\text { The fourth to } \\
\text { the late fifth } \\
\text { stage of the } \\
\text { rally }\end{array}$ & $\begin{array}{l}\text { The fourth to } \\
\text { the late fifth } \\
\text { stage of the } \\
\text { rally }\end{array}$ & $\begin{array}{c}\text { The second } \\
\text { stage }\end{array}$ & $\begin{array}{c}\text { Stage } 2 \\
\text { (previously } \\
\text { thought to be } \\
\text { Stage } 3 \text { but } \\
\text { then the curve } \\
\text { went down } \\
\text { again) }\end{array}$ & $\begin{array}{l}\text { The fourth to } \\
\text { the late fifth } \\
\text { stage of the } \\
\text { rally }\end{array}$ \\
\hline GNPpc phase & $\begin{array}{l}\text { According to } \\
\text { Dunning } \\
(1981): \\
\text { It's always } \\
\text { stage five } \\
\text { World } \\
\text { Investment } \\
\text { Development } \\
\text { Report (2006) : } \\
\text { Phases } 4 \text { to 5 }\end{array}$ & $\begin{array}{l}\text { According to } \\
\text { Dunning } \\
(1981): \\
\text { It's always } \\
\text { stage five } \\
\text { World } \\
\text { Investment } \\
\text { Development } \\
\text { Report (2006) : } \\
\text { Phases } 4 \text { to } 5\end{array}$ & $\begin{array}{l}\text { According to } \\
\text { Deng (1981) : } \\
\text { It's always } \\
\text { stage five } \\
\text { World } \\
\text { Investment } \\
\text { Development } \\
\text { Report (2006) : } \\
\text { Phases } 4 \text { to } 5\end{array}$ & $\begin{array}{l}\text { According to } \\
\text { Deng (1981): } \\
\text { It's always } \\
\text { stage five } \\
\text { World } \\
\text { Investment } \\
\text { Development } \\
\text { Report } \\
\text { (2006) : } \\
\text { Stage } 4 \text { to } \\
\text { Stage } 5\end{array}$ & $\begin{array}{c}\text { According to } \\
\text { Deng (1981): } \\
\text { It's always } \\
\text { stage five } \\
\text { World } \\
\text { Investment } \\
\text { Development } \\
\text { Report } \\
\text { (2006) : } \\
\text { Stage } 4 \text { to } \\
\text { Stage } 5\end{array}$ & $\begin{array}{c}\text { According to } \\
\text { Deng (1981) : } \\
\text { It's always } \\
\text { stage five } \\
\text { World } \\
\text { Investment } \\
\text { Development } \\
\text { Report (2006) : } \\
\text { Stage } 4 \text { to } \\
\text { Stage } 5\end{array}$ & $\begin{array}{c}\text { According to } \\
\text { Deng (1981) : } \\
\text { It's always stage } \\
\text { five } \\
\text { World } \\
\text { Investment } \\
\text { Development } \\
\text { Report (2006) : } \\
\text { Stage } 4 \text { to Stage } \\
5\end{array}$ \\
\hline
\end{tabular}


The test results show:

The quintuple model of developed countries has a better fitting effect, and the test of most countries is relatively significant, which does show the relationship between investment and economic development. However, the Dunning (1981) standard is obviously too low for developed countries, and the improved World Investment Report (2006) standard is more applicable.

Different countries are heterogeneous. From the perspective of economic development level represented by GNPPC, although these countries have the same level of economic development, their investment status is different.

In the fifth stage, as described by Dunning (1986), the net outward investment will not gradually fluctuate around the zero value. In many countries, the net outward investment will increase to a certain extent and then stay above a certain level, or even keep increasing.

\section{Conclusions and innovations}

\subsection{The applicability of measurement standards is not high}

From the cross-section, developing countries are relatively more applicable to Dunning's (1981) standard, while developed countries are relatively more applicable to the World Investment and Development Report (2006) standard, which has a higher standard. This indicates that the main reason may be the large gap between the rich and poor of developed and developing countries, which leads to the difficulty in standardizing the standards. From the internal perspective of Dunning's (1981) standard, it is obvious that with the development of time, the quantitative classification of economic development level has been unable to adapt to the development of The Times over the past 40 years, and the economic development speed of developing economies has surpassed the investment development.

On the one hand, the government can formulate corresponding policies to influence the internal economic structure of a country by promoting its investment, which may become an important foothold for the development of a country. On the other hand, the underdevelopment of investment is most likely due to the lack of ownership advantage of the country's enterprises, the scientific and technological strength is not strong enough to make largescale investment. For example, China's OFDI mainly relies on state-owned enterprises, which have abundant funds and have a special ownership advantage because of its domestic monopoly. ${ }^{\mathrm{v}]}$ However, to truly improve its international investment status, the strength behind the enterprises is the fundamental driving force, so it needs to rely on the scientific and technological power.

\subsection{The Fifth Stage of Industrialization: The Fifth Stage of IDP Theory}

According to the result of empirical test, found that the fifth stage of industrialization of countries did not show as the dunning said (1986) that in net foreign direct investment will fluctuate around zero value. As a result, it presented a rising trend, or maintain at a high level.

\section{References}

1. Dunning, John H. "Explaining the international direct investment position of countries: towards a dynamic and development approach", Weltwirtschaftliches Archiv, 117, pp. 30-64. (1981a).

"Explaining outward direct investment of developing countries: in support of the eclectic theory of international production", in K. Kumar and M. McLeod, eds., Multinationals from Developing Countries (San Francisco: Lexington Press), pp. 122. (1981b).

2. Buckley, P. J., and F. B. Castro . "The investment development path: The case of Portugal." Transnational Corporations 7.1(1998).

3. Khan, S. M. , and Z. S. Khan . "World Investment Report 2006, FDI from Developing and Transition Economies: Implications for Development by United Nations Conference on Trade and Development (UNCTAD). United Nations Publications, New York (2006). " Journal of Asian Economics 18.3:553-561. (2007)

4. Barry, F. , H. Grg, and A. Mcdowell . "Outward FDI and the Investment Development Path of a LateIndustrialising Economy - Evidence from Ireland." 341-349 (2001).

5. Gao, Zhi-xiong, and Lu, Jin-yong." The impact of digital connectivity on the investment development path theory: A case study of China." Asia-Pacific Economic Review, No.218.01:96-105+151-152. (2020). 